Journal of Southeast Asian Human Rights, Vol. 3 No. 2 December 2019 pp. 258 - 276

doi: 10.19184/jseahr.v\%vioi.13600

(C) University of Jember \& Indonesian Consortium for Human Rights Lecturers

\title{
First Post-Legislative Scrutiny in Georgia: Steps Towards Generating Result-oriented Laws
}

\author{
Kakhaber Kuchava \\ Environmental Protection and Natural Resources Committee Georgia \\ Email: kkuchava@parliament.ge
}

\begin{abstract}
The effective implementation of law is a complex process. This process depends on the availability of human resources, public engagement, funding (at least, on the stage of piloting), among others. Often, the focus is on getting legislation adopted, rather than on practical implementation and its impact. To fill in this gap, oversight over the Implementation of Normative Acts (i.e., Post-legislative scrutiny, hereinafter "PLS") has been introduced in the Rules of Procedures of the Parliament of Georgia (hereinafter, the "Parliament"). This article scrutinises the procedures that are shaping the Parliament's ability to conduct PLS as well as its interaction with the executive. The working theory for this paper is that insufficient attention has been paid to the review of legislation after its enactment in Georgia. The paper addresses the work that has been undertaken at the national level, particularly through monitoring the effects of adopted legislation in ensuring benefits for constituents in the ways initially intended. Furthermore, it will reflect on the challenges identified in the ongoing PLS process by the Environments Protection and Natural Resources Committee (hereinafter "Environment Committee") and the lessons learned based on the experience. The article uses a case study of Georgia to explore the context and challenges for effective PLS. For comparision, this research adopted the UK approach, where it is common to review the laws three to five years after enactment.
\end{abstract}

Keywords: Post-Legislative Scrutiny, Parliament of Georgia, Better Regulation, Legislative Process, Environment Committee

\section{INTRODUCTION}

The Parliament of Georgia is the supreme representative body of the country. It exercises legislative power and defines the country's domestic and foreign policies. Among executing other powers, Parliament ensures that the activities of the Government remain within the scope of the Constitution. 'Therefore, the effective

1 Constitution of Georgia, article 36(1), https://bit.ly/2I2h ZmS. 
functioning of Parliament is essential for the smooth operation of the Georgian governmental system, which is based on the balance of powers between state institutions.

The Parliament of Georgia made changes to the Constitution in 2017, through which the country has completely moved to a parliamentary model of governance. This stressed the necessity to strengthen the oversight mechanisms of the Parliament. The interest in "better lawmaking" and "better regulation" in the Europen Union (hereinafter, the EU) has dramatically influenced the Georgian legislation process in the light of the EU-Georgia Association Agreement. The scrutinising of the actual implementation of the existing EU legislative stock has been increasingly promoted in recent years, and is a core element of the "better regulation" package adopted by the Commission on May 2015. At its launch, Commission Vice-President Frans Timmermans emphasised the value of evaluation: "While the natural tendency of politicians is to focus on new initiatives, we must devote at least as much attention to reviewing existing laws and identifying what can be improved or simplified. We must be honest about what works and what doesn't".

As listed by Lord Privy Seal, Leader of the House of Commons, the need to monitor the implementation of legislation and to evaluate the impact of legislation is founded on four key arguments:

1. It is a requirement of democratic governance to apply the legislation adopted by Parliament in accordance with the principles of legality and legal certainty;

2. There is a need to act preventively with regard to the potentially adverse effects of recently adopted legislation;

3. There is a need for a consistent appraisal of the responsiveness of the law to the regulated problems and issues;

4. There is a need to learn from experience in terms of what works and what doesn't and how effective implementation is for meeting objectives. These should be considered with the aim of improving legislation in the future so as to reduce the need for corrective action. ${ }^{3}$

While the initiation of legislation is one of the essential tasks and powers of Parliament, the majority of legislation is instigated by the government, making the role of Parliament that of scrutiny/amendment. The growing impetus for the review of legislative impacts, especially that of the "quality check", has produced tangible

2 European Commission press release IP/15/4988 of May 19, 2015: Better Regulation Agenda: enhancing transparency and scrutiny for better EU law-making, https://europa.eu/rapid/pressrelease_IP-15-4988_en.htm.

3 The Law Commission, Post-Legislative Scrutiny, Published as LAW COM No 302, London, October 2006, 62 p. Post-legislative Scrutiny - The Government's Approach. Updating and improving the legislative process, Presented to Parliament By the Lord Privy Seal, Leader of the House of Commons and Minister for Women and Equality, March 2008, https://www.gov.uk/government/uploads/system/uploads/attachment_data/file/228516/7320.pdf 
outcomes. The Parliament adopted new Rules of Procedures in 2018 which puts particular emphasis on advancing Committees' roles and the transparency of the overall work of Parliament. Following that, two independent Parliamentary committees started to pioneer PLS for the first time in parliamentary history in Georgia. Environment Committee and Healthcare and Social Issues Committee took a number of steps with the same goal to review the enactment and impact of specific laws that were thematically connected to each committee. The following paper draws conclusions based solely on the ongoing PLS in Environment Committee and respectively reflect the challenges identified in this regard.

Following the adoption of a new Rules of Procedure, at the initial stage, the Environment Committee selected a particular article to review. Although no formal group was formed to work on the matter, the Committee and its Apparatus agreed to join in helping to conduct the very first successful PLS process, and through this process, they motivated other committees to incorporate PLS in their routine. To understand the process entirely, it is essential to break down the details of the current PLS of Environment Committee. After selecting an article for review, the same approach was applied as is applied to thematic inquiry (referred as committee inquiry in the UK). This means that the relevant stakeholders were invited to the presentation about the PLS, and Terms of Reference (ToR) were elaborated. The stakeholders were invited to submit a written opinion. Along with receiving opinions, the desk research was carried out to study article-related trends, state incentives, related sublegislative acts, judiciary practises and other relevant materials.

Currently, the materials are summarised and the Environment Committee, within its competencies, is finalising the report. The Committee plans to take appropriate measures to eradicate legislative flaws and address unintended consequences. ${ }^{4}$ Further potential measures that can be taken by committees is not precisely prescribed in the Rules of Procedure of Parliament, only to take the necessary measures to ensure proper enforcement of normative acts. Consequently, the Committee can options as they see fit. One example of this is amending regulations so as to address the legal deficiencies.

Although the PLS process seemed to be prearranged by the Committee, some issues still manifested vividly. Upon reflection, solutions for those issues are simple and straightforward: the only way to support improvement is through analysing existing scrutiny gaps and addressing other matters of concern. In this way, the process of carrying out PLS can be defined as an objective activity that enables Parliament to reflect on internal technical abilities as well as the broder implications of their work on the merits of their democracy. Generally, a good legislative procedure consists of five key stages: consultation, drafting, adoption, implementation, and oversight. In those processes, objectivity plays a key role. This is especially true for PLS, which is only now

4 The Parliament of Georgia, Rules of Procedure of the Parliament of Georgia, article 38(2) (Tbilisi: The Parliament of Georgia, 2019). 
being piloted by the Parliament of Georgia. Objectivity can be ensured in numerous ways. For example, ensuring the transparency of the process would be one which, through its practice, leads to greater accountability, better decision-making, and greater public involvement throughout the decisive process. While piloting PLS, Environment Committee published relevant materials on the website, held consultations with experts, and reviewed best international practices to ensure objectivity. It is also worth noting that the Committees would benefit from having a comprehensive list of all required actions of the PLS process.

\section{THE CONCEPT OF EVALUATION IN GEORGIAN CONTEXT}

When reflecting on the concept of PLS, it is important to mention that in October 2004, the Constitution Committee of House of Lords contributed commentary regarding the legislative process. The Committee contributed the following remark to begin a section on PLS: "Post-legislative scrutiny appears to be similar to motherhood and apple pie in that everyone appears to be in favour of it. However, unlike motherhood and apple pie, it is not much in evidence". As explained by researcher Lydia Clapinska, the quotation above is a rational statement if the evaluation of legislation is considered to be a principal constituent of legislative methodology. This argument is difficult to refute because Parliament's effectiveness is often assessed according to its legal oversight mechanisms, experience in exercising parliamentary oversight, the political will of internal MPs, and the responsiveness of the Government. Furthermore, Clapinska stresses that, in the private sector, "quality control" is a familiar phrase used to refer to the investigation into if a particular product or service is fundamental to the success of the business in question. ${ }^{6}$ However, when it comes to legislation review, the process of assessment and/or evaluation is a relatively new concept. The conceptualization of "quality control" is only now beginning to gain ground in the Georgian Parliament.

PLS is a broad concept. Put it simply, it is an inquiry by a Parliamentary committee into how a new law has worked in practice since it came into force and if it served the aims initially defined by lawmakers. As Maria Mousmati points out, it is not uncommon for the review process for the implementation of legislation to be overlooked. For this reason, there exists risk that laws are passed but not applied,

5 House of Lords, Select Committee on the Constitution, 14th Report of Session 2003-04: Parliament and the Legislative Process (London: The Stationery Office Limited, 2004), https://bit.ly/2QDjVES.

6 Lydia Clapinska, "Post-Legislative Scrutiny of Legislation Derived from the European Union," (MA thesis, Institute of Advanced Legal Studies, School of Advanced Study, 2006), 7, https://bit.ly/2Xyo1AC. 
secondary legislation is not adopted, and/or there is a lack of sufficient data for the assessment process of the actual state of a law's implementation and its effects.

There is no generally accepted theory regarding proper applications of PLS. Therefore, the practices are inconsistent. In daily practice, PLS unfolds through differentiated approaches and solution-implementation. Regarding this characteristic, Elena Griglio has stated "this makes it challenging to trace a common line of development in different countries." As explained by Franklin De Vrieze, there are two types of PLS: (i) that which refers to broad legislative review, the purpose of which is to evaluate whether and to what extent a piece of legislation has achieved its intended purpose; and (ii) that which refers to a more focused evaluation of how a piece of legislation works in practice. The latter type is more concentrated and tends to be a purely legal and technical review. ${ }^{9}$

Different countries have applied various methods to trigger the PLS process. These include constitutional provisions, legislative requirements (laws on law-making \& improved legislation), policy documents, or intergovernmental processes. According to The London Declaration, PLS typically involves checking two dimensions of the normative act. This first check investigates whether the legal provisions of the law have been brought into force. The second investigates whether the intended objectives of the law have been met adequately. ${ }^{10}$ In Georgia it is up to the Committee to trigger PLS.

PLS is regulated by the Rules of Procedure of the Parliament of Georgia. As per regulation, "the Committee oversees the state of enforcement of normative acts adopted by the Parliament in the Committee's specific field. With this purpose in mind, it studies and analyses their efficiency; considers any obstacles that may have emerged since they became effective; considers the necessary measures to eradicate obstacles, as well as objective factors that prevent their proper enactment; and takes appropriate measures to ensure their enforcement". "As per regulation in Rules of Procedure, the Parliamentary hearing may take the place of the state for the enforcement of a normative act. If necessary, the Parliament may adopt a decree that may reflect (a) the Parliament's evaluation regarding the implementation of the normative act; (b) assignment of the normative act to a respective Committee for

7 Maria Mousmouti, Legislative aspects of Post-Legislative Scrutiny, Institute of Legal Advanced Studies, London, July 2019.

8 Elena Griglio, "Post-Legislative Scrutiny as a Form of Executive, Oversight Tools and Practices in Europe", accessed on July 7, 2019, European Journal of Law Reform 2019 (21) 2, accessed July 7, 2019. doi: 10.5553/EJLR/138723702019021002004.

9 Franklin De Vrieze and Victoria Hasson, "Post-legislative scrutiny: Comparative study of practices of Post-Legislative Scrutiny in selected parliaments and the rationale for its place in democracy assistance" London, 2017. Accessed June 2, 2019, https://bit.ly/2VtCcWf.

10 Westminster Foundation for Democracy, Championing Parliamentary Oversight: The London Declaration on Post-legislative Scrutiny (London: Westminster Foundation for Democracy, 2018), https://bit.ly/2EXYaLl.

11 The Parliament of Georgia, Rules of Procedure, article 38(I). 
requisite corrections. ${ }^{12}$ Furthermore, it is vital to consider the timing required to conduct PLS. For the findings to be the most effective, it is most beneficial to conduct review between three and five years after enactment of the law. In Georgia, there is no formal requirement for PLS to be carried out. However, upon consideration of the local context, the Environment Committee consider two to four years after enactment as a reasonable window of time during which PLS implementation should begin.

In addition to timing, it is crucially important to think through government responsiveness to PLS. In the UK, PLS is accompanied by the an expectation that the government will publish a memorandum regarding the implementation. As Franklin De Vrieze, consultant on parliamentary development, puts it in his comparative study on PLS, "the primary audience of these memoranda is Parliament and, in particular, the Select Committees of the House of Commons. The referent department tables its Post-Legislative Scrutiny Memorandum with the relevant House of Commons Select Committee, who must then decide whether further inquiry is needed."14

To put the above-mentioned within the Georgian context, and to draw conclusions, it must be noted that "an early report runs the risk of immature judgment on the impact of legislation. While it is hard to set a general timeframe for PLS, between three to five years after enactment sounds reasonable. ${ }^{15}$ It might be reasonable to predetermine the date of review in the regulation itself.

\section{IDENTIFIED CHALLENGES OF POST-LEGISLATIVE SCRUTINY}

Rushing into legislation hardly ever makes sense because hasty and poorly-considered law often causes more difficulties than it solves. Some see the ease with which legislation can be introduced as problematic. It has resulted in, as Paul Silk puts in his research, "a legislative tsunami", with log-jams of draft laws that tend to make little or no progress at all, and do not comply with basic requirements of procedural compliance. ${ }^{16}$

At the same time, the need to keep legislation up to date has been expressed through the opinion of Advocate General Bobek in the European Court of Justice Case C-528/16. Although it is hard to predict to what extent the Advocate General's opinion will be taken on board in the forthcoming Court ruling, it nonetheless seems pertinent to refer to his opinion, as it directly relates to issues of legislative review. The Advocate General stressed that "failure to keep that instrument up to date could result

12 The Parliament of Georgia, Rules of Procedure, article 38(4).

13 See note 9 above.

14 Ibid.

15 Franklin De Vrieze, "Post-Legislative Scrutiny: How Parliaments Review the Impact of Legislation," Political Studies Association Specialist Group on Parliaments, accessed June 2, 2019, https://bit.ly/310G2dd.

16 Paul Silk, "End to end legislative process: some international examples of good practice". Accessed June 2, 2019, https://bit.ly/2WugyGz. 
in extreme cases of technical or social lack of responsiveness or in a potential declaration of invalidity of the specific legislative provisions because of inactivity, particularly that regarding to a failure to amend the legislation in question." ${ }^{, 7}$

Depending on how well the PLS is planned and conducted, it can either be fruitful or can cause ambiguity and underestimate the importance of PLS. This has especially been true in non-Westminster Parliaments, where such oversight mechanisms have yet to gain ground. Wise and results-oriented planning should accompany the parliamentary process so that the law can speedily be brought into effect. This statement is particularly important as it relates to the EU-Georgia Association Agreement and the ongoing process of harmonisation. Also, it is important to note is that PLS should not be used as an opportunity to re-run any political arguments that took place when the law was initially being considered. The process is purely technical and must remain so. The ongoing PLS in Environment Committee and the comparison to the UK process revealed five main challenges for newly formalised PLS. The list is not exhaustive, but it reflects critical issues:

1. Existing regulation of PLS is general. This leaves the room for informational gaps which, in turn, increase the risk of misinterpretation. In order for this to be avoided, detailed guidelines are to be elaborated promptly;

2. Parliamentary Staff need to be trained to perform PLS independently and the process should not depend on financial contributions from external sources such as donors;

3. Engagement of relevant stakeholders in the PLS seems to be low because PLS is a relatively new mechanism, for which there is not enough public awareness. Furthermore, some topics trigger more interest in society depending on their relevance to the daily lives of citizens;

4. Historically, the Parliament of Georgia lacked prearrangements for consistent monitoring of the enactment and impact of normative acts/laws/regulations;

5. There are many similarities between the Thematic Scrutiny, Regulatory Impact Assessment (RIA) and PLS. These parliamentary oversight mechanisms are relatively novel in the Georgian Parliament. The first thematic inquiry has been conducted by the Environment Committee recently, therefore it should not be surprising that Parliamentary Apparatuses have found it difficult to differentiate between appropriate tools for specific cases, as well as how to report on their cases generally.

Although the Westminster model tends to be viewed as the archetype, there is no single model or universal method for PLS. To advance the process of PLS, and to provide an example for countries currently developing their PLS procedures, the five aforementioned challenges are analysed below.

17 Opinion of Advocate General Bobek in Case C-528/16 - Confédération paysanne and Others, Court of Justice, January 2018, point 139. http://curia.europa.eu/juris/celex.jsf?celex $=62016$ CC0528\&lang $1=$ en\&type $=$ TXT\&ancre $=$. 


\section{Existing Regulation of Post-Legislative Scrutiny}

As mentioned earlier, topic-specific Parliamentary Committees oversee the enforcement of normative acts within their field of concern. With this purpose, Committees analyse the efficiency of these acts, considers any difficulties that have emerged since the normative act(s) became effective, and identify the measures necessary to eradicate these obstacles. In addition, they consider the objective factors that prevent proper enactment, and list appropriate steps to ensure proper enforcement. ${ }^{18}$

The Committee, within its competencies, analyses the judiciary practice and takes appropriate measures to eliminate legislative flaws. Furthermore, The Bureau of the Parliament is authorised to add issues of enforcement of normative acts to the agenda of the plenary. Issues are then discussed according to the rules established by the Rules of Procedure for the first hearing of a draft law. After the parliamentary hearing of the state of the enforcement of a normative act, if necessary, the parliament adopts a decree that may reflect: (a) the Parliament's evaluation of the implementation of the normative act; and (b) assignment to a respective Committee, who will then make appropriate corrections to the normative act.

The Committee, within its competencies, analyses judiciary practice (if available) and responds appropriately so as to eradicate legislative flaws. PLS has particular importance in Georgia because it is a tool used to monitor government. However, no details for elaboration exist within the Rules of Procedure in Georgia, which highlights the need for a PLS methodology. Conversely, the Westminster Parliament has a wellestablished system of PLS. This establishes that all select Committees should conduct PLS as part of their routine scrutiny work. PLS can extend beyond executive oversight and serve as an internal monitoring and evaluation system. Franklin De Vrieze stresses that by such system "Parliament is also able to consider and reflect on the merits of its democratic output and internal technical ability." ${ }^{19}$ In this way, PLS provides an approach by which Parliament may assume its role as a country's legislative watchdog.

Some scholars point out that in the UK "there is a bias in the legislation being selected to receive post-legislative scrutiny and that Committees, on the whole, are producing weaker recommendations which are more likely to be accepted. Additionally, it concludes that the stronger the action that a recommendation calls for, the more likely it is to be rejected." ${ }^{20}$ This is a point which the Georgian, and all nonWestminster parliaments, should consider.

18 See note 11 above.

19 See note 9 above.

20 Thomas Caygill, "Legislation under Review: An Assessment of Post-Legislative Scrutiny Recommendations in the UK Parliament," The Journal of Legislative Studies 25:2 (2019): 295-313, accessed on June 2, 2019, doi: 10.1080/13572334.2019.1603260. 
The first step towards generating result-oriented laws is relaying parliamentary control to a more accountable government. Accountability, in this context, is defined as lively, precise and responsive to changes in the environment in which it operates. There is, however, a broadly-held belief that an accountable government involves responsiveness and that it is the requirement of governments to inform, explain and justify, and the responsibility of the accounting agency (Parliament) to impose sanctions. As Thomas Caygill notes, it is to be expected that PLS leads to many recommendations regarding actions to be taken about legislation. These may refer to the implementation of an act, or amendments to sections of an act. ${ }^{21}$

The effective regulation of PLS, unlike Thematic Inquiry, is broad and leaves potential procedural information gaps. To remedy this, a detailed guidebook on how to conduct PLS is being prepared by the external expert for the Georgian Parliament. In this regard, one has to bear in mind that while regulating PLS or any mechanism, the flexibility of the tool must be maintained.

\section{Identification of Parliamentary Apparatus Needs}

As technical and financial support is required to perform PLS, before the Committee Apparatus can begin work, the involvement of donors is required. This kind of Parliamentary support is an essential investment in the continued rooting of a stable democratic system in Georgia. The need for external human resources indicates that there is a crucial need for the training of staff who will conduct PLS and related activities such as gathering data from multi-disciplinary sources. Another consideration that arises during the PLS-implementation process is that which concerns the method for documentation of objectives. Parliament stakeholders recognise that PLS is an imperative part of the formal legislative procedure. However, the Parliament of Georgia lacks a proper, evidence-based, research-informed approach to the PLS process. Reflection on the UK experience provides insights and potential solutions.

St. John Bates pointed out the well-known political, drafting and procedural pitfalls of using purpose clauses. He also recognized that it is doubtful that even an elaborate purpose clause would provide the required amount of detail for thorough postlegislative review. ${ }^{22}$ In response, the Government agreed that explanatory notes should indicate the purpose of a bill. However, the Government was not convinced that explanatory notes would sufficiently ensure the appropriate handling of PLS. Arguments for and against explanatory notes can be circulated over and over again. While the Government favoured policy documents, Professor St. John Bates pointed out, this would be "procedurally ineffective" and a "rather untidy" approach. ${ }^{23}$

21 Ibid.

22 See note 3 above.

23 Ibid. 
In the case of Georgia, the Environment Committee considers it reasonable to use the explanatory note of a legal act to scrutinise its enactment and the impact of the regulation. This practice ensures the advancement of the quality of the explanatory notes and may serve as a great starting point to measure the success of the regulation itself (i.e. enactment and impact of law). The Parliament of Georgia lacks sufficient human resources to implement PLS adequately. This is seen through the tendency that explanatory notes attached to draft legislation remain basic through years, and often do not provide an accurate picture of the reasons for preparing the draft law. This is a widespread practice, both in the Government and in the Parliament, that needs to be addressed.

Through the formalisation of PLS in Parliament and its piloting by the Environment Committee, it has become clear that that there is a need for at least one lawyer in the Committee Apparatus. This need is clear because of the lack of general guidance during the current legislative drafting process. There needs to be a higher concentration of the specialist skills and resources required for legal writing within the Parliamentary Apparatus, as well as more guidance on such drafting, apart from the basic minimum standards provided for by the relevant laws.

Currently, there exist no written guidelines or manual for drafting legislation, though certain efforts to develop such guidelines are underway. The unavailability of a legal drafting manual further exacerbates the problem, which cannot be adequately addressed through legislative provisions alone. Another pressing issue is that inadequate resources are made available for the drafting process. The Environment Committee has five people in the Apparatus, and the load of work allocated to each individual is more than is reasonable, which results in the reduced quality of the work. More precisely, the learning process for drafters is almost completely confined to "learning by doing". It appears to be a widely-shared concern that the Parliament suffers from a lack of well-trained human resources that would provide adequate technical support to the procedure.

Considering the availability of human resources, the Committees must wisely select legislation for review. It is better to focus on quality rather than quantity and review less articles annually in greater detail, rather than reviewing multiple acts a year in a less thorough manner. To address deficiencies, it might also be useful to develop a PLSspecific capacity development plan for the Committee Apparatus. The training should include relaying of methodologies for scrutinising legislation; evaluation and reporting techniques; cost-benefit analysis; and legislative research; to maximise the capabilities of assistance in the exercise of parliamentary oversight.

As Iurie Pîntea and Peter Vanhoutte state in their study, a standardised PLS methodology can help guide the process of establishment of clear evaluation rules and indicators; smooth the designing of a transparent process for review; and aid with the establishment of clear divisions of responsibilities and make sure that the results of the 
evaluation are effectively used to inform future decisions. ${ }^{24}$ Furthermore, as Franklin De Vrieze puts it, best practice indicates that it is best to review laws and regulations that relate to emergency situations under fast track procedure. It is also useful to simultaneously review secondary or delegated legislation and the primary act. ${ }^{25}$ The factors mentioned earlier might ensure that the PLS process is fruitful.

\section{Engagement of Constituents and Other Relevant Stakeholders in PLS}

Evaluation of the effects of a piece of legislation is fundamentally related to a legislator's responsiveness to social reality. Public involvement in PLS enables access to additional sources of information as well as increases the credibility of findings and the accuracy of data. In doing so, it enhances public trust in democratic institutions. ${ }^{26}$ The results of PLS, such as the PLS Committee report, need to be publicly accessible. Georgia follows this approach by publishing all its reports and other material on the website of Parliament. Even so, engagement with civil society organisations, citizens, and all others affected by the specific laws is still challenging due to a lack of awareness about PLS. This is likely because PLS is a relatively new concept in Georgia. To remedy this, Committees must be more active with PLS tools and consider greater incorporation of PLS discussions and considerations into their daily routines.

The PLS process should be people-oriented and systematic, but at present, Parliament does not employ this approach. Regulations tend to be addressed in isolation from what has gone before and from what may happen later. Most laws are only an exclamation point in a continuous process of developing and applying peopleoriented policies. Committees are invited to include outreach and public engagement as part of the PLS process because these activities result in better-informed regulations and laws that pull from diverse sources of information and evidence. Committee public hearings or consultations can further enhance public trust in Parliament and other democratic institutions, thereby increasing civic engagement in the decision-making process of Parliament. Best parliamentary practices would have PLS reports available to the public whenever possible. ${ }^{27}$

It is important that independent or autonomous stakeholders report to Parliament on how certain legislation has been implemented, to identify any issues with implementation and whether the legislation actually addressed the difficulty that it was intended to address. As the Organization for Security and Co-operation in Europe

24 Iurie Pîntea and Peter Vanhoutte, "Post-Legislative Scrutiny, practices, experiences and recommendations”. January 2017, Chisinau, Moldova, http://ipp.md/old/public/files/Publica $\underline{\text { tii/Post legislative scrutiny practices experiences recommendations.pdf. }}$

25 See note 17 above.

26 Franklin De Vrieze, Principles of Post-Legislative Scrutiny by Parliaments (London: Westminster Foundation for Democracy, 2018), https://www.wfd.org/wp-content/uploads/2018/07/Principles-ofPost-Legislative-Scrutiny-by-Parliaments.pdf.

27 See note 10 above. 
(OSCE) puts it, "to maximise the value of stakeholder engagement, it is important to ensure their participation from an early stage of full legislative cycle." ${ }^{28}$ From that perspective, current Committees should review the effectiveness of public engagement in PLS. Such a review should examine how the use of technology could be used to maximize the engagement, and as a result, the benefits of public engagement. Notably, the Environment Committee actively uses its social networks to disseminate the information and engage civil society at all stages of ongoing processes.

While there is a growing awareness of the need for PLS of legislation, the current PLS practice showed that public engagement strongly depends on whether the selected normative act corresponds to the daily life of citizens. As OECD pointed out in regulatory policy outlook, engaging with those concerned and affected by regulation is fundamental for the improvement of regulation design, compliance, and public trust. ${ }^{29}$

To sum up, the participation of relevant stakeholders in the full legislative cycle is central to democracy because it produces better laws and, consequently, fewer amendments. To ensure the sustainability and efficiency of PLS, Committees are invited to conduct it in an inclusive process in which all party groups, regardless their political views, can participate.

\section{The Difficulties of Enforcement}

The need for post-legislative scrutiny is especially pressing in the light of rapidly increasing amounts of enacted legislation. Much of which does not, due to practical constraints, receive the greatest possible scrutiny during the legislative process. Much of this primary legislation generates further regulations, either in the form of secondary legislation, or as supplementary codes and guidance. Under these conditions, law enforcement is a complex process which involves numerous activities.

To address the issue of poor monitoring and evaluation, PLS must be systematized in a way that maintains the flexibility of the process. As an example of this model, one can look to the recommendations made by The Law Commission of the UK Parliament. The Commission recommended using a more systemic approach for four headline reasons: "(1) to see whether legislation is working out as intended in practice; (2) to improve the implementation and delivery of policy aims; (3) to contribute to the formation of better regulation; and (4) to identify and disseminate good practises so that lessons may be drawn from the successes and failures revealed by the scrutiny work." ${ }^{30}$

28 OECD, Better Regulation Practices across the European Union (Paris: OECD Publishing Paris, 2019), 41, https://doi.org/10.1787/9789264311732-en.

29 Organisation for Economic Co-operation and Development (OECD) regulatory policy outlook 2018, October 10, 2018, https://doi.org/10.1787/9789264303072-en.

30 The Law Commission (LAW COM No 302), Post-legislative Scrutiny CM 6945 (London: The Stationery Office Limited, 2006). 
Along with the difficulties of enforcement, the Law Commission of the UK also commented on the risks and limitations of PLS. These concerns also relevant to the Georgian context. ${ }^{31}$ The most pressing of which include the risk of a replay of arguments, dependence on political will, and resource constraints. Unless exercised by the Parliament and Government, there is a risk that PLS discussions may turn into a mere replay of arguments that arose during the passage of the law. David Laverick observed that "there is a danger that the more wide-ranging scrutiny that may arise during discussions about whether the legislation has achieved its social or political purpose will reopen debates about the merits of that purpose". ${ }^{32}$ As De Vrieze puts it, another recognised risk, as mentioned above, is the lack of political will, which is the most significant hurdle in the road to more a systematic process of post-legislative scrutiny. However, Parliament and Government should recognise their shared investment in strengthening PLS as it helps to deliver clarity to the legislative process and ensures that the resources devoted to legislation are effectively utilized. Also, De Vrieze, in his comparative study about PLS, refers to the necessity of information accessibility. He notes that to increase the effectiveness of PLS, access to governmentheld information is vital. In the UK, access is secured through an agreement between Parliament and government to produce an outline ministerial memorandum on the implementation of legislation. ${ }^{33}$

Last but not least, as PLS is just gaining the ground in Georgia, it must be understood that PLS review is a "no-blame" process. Seeking to "name and shame" would be as counterproductive. It would reduce the credibility in general terms if PLS is seen to be constantly open to being re-argument.

\section{Similarities with Other Mechanisms of Oversight}

Along with formalisation of PLS, several other related mechanisms were adopted by the Parliament. For the aims of this article, special attention is paid to thematic inquiry. There are many similarities between PLS and thematic inquiry though they are two conceptually different mechanisms of oversight. Unlike PLS, thematic inquiry procedures are elaborated in greater detail. According to Rules of Procedure of Parliament, based on the decision of a Committee or permanent Parliamentary councils, a thematic inquiry group formed from MPs may be appointed to study an important issue and develop a relevant draft decisions. ${ }^{34}$ In line with the conclusions, a committee or the Parliament shall develop recommendations or exercise other powers prescribed by the Rules of Procedure. Recommendations and/or tasks developed by the committee/the Parliament shall be sent to relevant administrative bodies and must

31 See note 22 above.

32 See note 28 above.

33 See note 17 above.

34 OECD, Introductory Handbook for Undertaking Regulatory Impact Analysis (RIA), Version 1.0 (2008), http://www.oecd.org/gov/regulatory-policy/44789472.pdf. 
be made publicly available on the website of the Parliament. While there is no clear rules for the selection of a piece of legislation to review in the frame of PLS, in the case of thematic inquiry, any member of a committee (or a group of MPs) is entitled to present a list of issues for consideration. These may include those triggered by ongoing events, public interest, or other factors. ${ }^{35}$

During the thematic inquiry of an issue, it is mandatory to hold a hearing during which interested persons, specialists of the relevant field(s), and experts and representatives of administrative bodies related to the issues shall be invited. ${ }^{36}$ Such procedures are not mandatory during PLS. Furthermore, thematic inquiry groups are responsible for the following activities: development of a scrutiny plan and schedule; determining specialists who will participate in the scrutiny; generally lead the process; hold responsibility for studying the issue and developing a draft decision; study information/evidence submitted by interested persons; and exercise the right to request and receive information and explanation(s) on any issue from administrative bodies. ${ }^{37}$

A thematic scrutiny group shall prepare and submit a report to the Bureau or Committee of the Parliament. The report shall be submitted to the Bureau of the Parliament and upon necessity or special request decide to add the issue to the agenda of the plenary sitting of the Parliament. Unlike thematic inquiry, PLS is more of a routine work done by the Committee Apparatus/MPs rather than a selected topic for inquiry, which would require more time and resources.

The principal differences between these two tools must be pointed out. First, PLS is a tool solely concentrating on reviewing normative acts adopted by the Parliament. Second, unlike thematic inquiry, PLS has pre-determined aim to "(1) evaluate the introduction and enforcement of a piece of legislation, thus whether the legal provisions of the law have been brought into force. ${ }^{38}$ More precisely, Thematic Inquiry is not limited to reviewing normative acts adopted by the Parliament, rather, any legal regulation or topic can be analysed. Furthermore, while selecting the topic for Thematic Inquiry, the Committee shall consider a so-called "hot topic" meaning that if the specific subject triggers high interest in society/media, it can further proceed to form a working group and start an inquiry for; "(2) evaluating the impact of legislation, thus if its intended policy outcomes have been met." ${ }^{{ }^{39}}$

Numerous times, questions regarding the difference between PLS and RIA have been posed to the Environment Committee. To address confusion, the main difference between these two mechanisms should be pointed out. RIA is a systemic approach to critically assessing the positive and negative effects of proposed regulations and nonregulatory alternatives while PLS is an opportunity to verify and evaluate the possible

35 See note 4 above.

36 The Parliament of Georgia, Rules of Procedure, article 155(7).

37 See note 12 above.

38 See note 10 above.

39 Ibid. 
benefits, expenses and results of the law. ${ }^{10}$ It represents the process that identifies and evaluates the expected outcomes and impacts stemming from the regulation. To put it simply, RIA is a document created before a new law/regulation is introduced and the PLS in post evaluation of normative acts.

It must be noted that the initiative to institutionalise RIA is a positive step towards better regulation. RIAs provide an excellent platform for the clarification of policy objectives and the setting of standards for monitoring and review. Consequently, RIAs should be enhanced to incorporate these considerations more effectively. It has been assessed as a step forward by various organisations, however, these organizations also put forward numerous recommendations that require careful consideration. ${ }^{41}$

An interesting observation has been made by the scholars Jonathan Murphy and Svitlana Mishura. Namely, they pointed out that non-Westminster Parliaments have received comparatively less scholarly and parliamentary development-practitioner attention regarding PLS. ${ }^{2}$ To address this is a gap in Parliament of Georgia, Environment Committee plans to make PLS an inevitable part of Committee's work. In doing so, Committee Apparatus specialists will have to come up with a possible list of laws for the evaluating of its enactment and impact. While selecting the laws, Committees will act under the broad topics (for example, forests, water, biodiversity) that they are assigned to. In that way, the Environment Committee will test its ability to make PLS a regular process.

In general, greater attention is being focused on the roles of Parliamentary Committees in the Parliament of Georgia, particularly that of oversight. Formerly, discussion tended to focus only on the legislative output of Committees. Following that trend, to execute oversight functions more effectively, the Parliament of Georgia requires an oversight manual. On its turn, this would allow Committee Apparatuses to perform its oversight function, including PLS, without the need for external financial and human resources. The oversight manual must be comprehensive. It must contain tools, techniques, and procedures that comply with local context but are also in line with international best practices. The manual would improve the overall environment in which oversight is carried out, build the Parliament's institutional capacity for oversight, and reinforce the will among Parliamentarians to carry out PLS regularly.

40 The Parliament of Georgia, Explanatory Note of the Draft Amendments to the Law of Georgia on Normative Acts (Tbilisi: The Parliament of Georgia, 2019).

41 "Institutionalization of Regulatory Impact Assessment (RIA) in Georgian Legislation," Transparency International Georgia, accessed June 3, 2019, https://www.transparency.ge/en/blog/institutionalization-regulatory-impact-assessment-ria-georgianlegislation.

42 Jonathan Murphy and Svitlana Mishura, "Post-legislative Scrutiny in a Non-Westminster Parliament," European Journal of Law Reform 2 (2019), https://www.elevenjournals.com/tijdschrift /ejlr/2019/2/EJLR_1387-2370_2019_021_002_003. 
To conclude, a clear line must be drawn between the three, conceptually-distinct, aforementioned tools and their applications. This is a matter to be decided on a caseby-case basis, in which analysis occurs based on the aim to be achieved.

\section{CONCLUSION}

This research reflected on work undertaken by the Parliament of Georgia for monitoring the effects of adopted legislation using PLS. It revealed evaluation gaps of PLS on the one hand and stressed the potential for evaluation of normative acts on the other. The understanding used in this paper is that PLS is a broad form of evaluation intended to address the effects of the legislation in terms of whether legislation has met the intended policy objectives and, if so, guages the effectiveness. PLS does not impede Committees' ability to narrow its assessments to a particular piece of law.

The European Economic and Social Committee acts in an advisory capacity for European Parliament. The Council has defined better lawmaking as "looking at a situation from the viewpoint of the user of the legal instrument". ${ }^{43}$ With this definition in mind, there is a need for some form of evaluation or "quality control" to see whether the end product of the legislative machine is working. In this light, the timing used to develop PLS in Georgian Parliament seems to be perfect. In the EU-Georgia Association Agreement, transparency is demanded in the interests of democratic processes and accountability. There used to be a front-end emphasis on producing vast quantities of legislative output. Nowadays, the focus has shifted to the legislative output, and Georgia is following that path.

To take better account of national context, this paper proposes a rebalancing of the dialogue concerning PLS in non-Westminster Parliaments through proposing improvements approaches to PLS development in Georgia. Improvement of PLS could be used as a guide by other parliaments in which PLS has not previously been used. An interesting remark has to be pointed out: the piloting of PLS and the Thematic Inquiry by the Environment Committee for the first time in the history of Georgian Parliament has revealed that, while Thematic Inquiry is a massive process requiring a broad range of activities and can be related to any topic, it should be integrated into the daily routine of the apparatus. Another interesting observation is that, while piloting PLS and Thematic Inquiry, Committees have invested much time and effort into increasing the capacity of the Committee Apparatus and, despite their efforts, have faced significant challenges. On the one hand, Parliament is still working to develop its organisational capabilities, which affects the quality of parliamentary work, especially when the new tools are introduced. On the other hand, the

43 Opinion of the European Economic and Social Committee on Better Law Making, Official Journal C 24, 31 January 2006, 39, quoted in Lydia Clapinska, "Post-Legislative Scrutiny of Legislation Derived from the European Union," (MA thesis, Institute of Advanced Legal Studies, School of Advanced Study, 2006), 51. https://sas-space.sas.ac.uk/241/1/Lydia_Clapinska_MA_THESIS.pdf. 
requirements and expectations, as generally related to the quality of parliamentary work and legislative function, have significantly increased.

PLS is a potentially-important new area of Committee activity. Knowing this, it might be beneficial to evaluate the outcomes of the first PLS. Other Committees may also learn from the PLS conducted by the Environment Committee and use that learning while planning/initiating PLS for other normative acts. In this regard, one thing is quite clear: PLS provides a useful starting point from which democracy practitioners may improve Parliament's internal capabilities. It provides a starting point which is grounded in a tangible area of delivery within a Parliament's micro-level structure, but also has substantial implications on the effectiveness and efficiency of the broader governance of a country.

There are indications that PLS is beginning to be swept along with the better regulation agenda in Georgia. As far as further steps, Parliamentary and Governmental systems should be adapted to allow for a more systematic implementation of PLS for normative acts.

In the final analysis, it must be emphasised that it is in nobody's best interest to produce deficient legislation in the country. The fact that there are drives towards assessing the enactment of law and quality of impact shows that the PLS-oriented review of normative acts in Georgia can be viewed as a guiding example for other parliaments. The practice of the UK shows that Committees should give routine consideration to if and how legislation will be monitored and reviewed.

PLS, as implemented in line with the pre-determined methodology, offers an excellent way for the Georgian Parliament to strengthen parliamentary oversight, one of their critical tasks. As part of the European integration process, PLS allows for the reviewing of the quality of the implementation of new and amended legislation as part of the overall progress of the association-process. For Members of Parliament, PLS provides additional opportunities for interaction with the citizens they represent as well as a tool for effective oversight on the government.

\section{BIBLIOGRAPHY}

Caygill, Thomas. "Legislation under Review: An Assessment of Post-Legislative Scrutiny Recommendations in the UK Parliament." The Journal of Legislative Studies 25:2 (2019): 295-313. Accessed June 2, 2019. https://doi.org/10.1080 /13572334.2019.1603260.

Clapinska, Lydia. "Post-Legislative Scrutiny of Legislation Derived from the European Union.” MA thesis, Institute of Advanced Legal Studies, School of Advanced Study, 2006. https://sas-space.sas.ac.uk/241/1/Lydia_Clapinska_MA_THESIS.pdf.

Constitution of Georgia, article 36(1). https://matsne.gov.ge/en/document/download/ $30346 / 35 / \mathrm{en} / \mathrm{pdf}$. 
De Vrieze, Franklin. "Post-Legislative Scrutiny: How Parliaments Review the Impact of Legislation." Political Studies Association Specialist Group on Parliaments. Accessed June 2, 2019. https://parliamentsandlegislatures.wordpress.com/2017/ 12/13/post-legislative-scrutiny-wfd/.

De Vrieze, Franklin. Principles of Post-Legislative Scrutiny by Parliaments. London: Westminster Foundation for Democracy, 2018. https://www.wfd.org/wpcontent/uploads/2018/07/Principles-of-Post-Legislative-Scrutiny-by-Parliaments.pdf

Dr. Maria Mousmouti, Legislative aspects of Post-Legislative Scrutiny, Institute of Legal Advanced Studies, London, July 2019.

European Commission press release IP/15/4988 of May 19, 2015: Better Regulation Agenda: enhancing transparency and scrutiny for better EU law-making. Accessible https://europa.eu/rapid/press-release_IP-15-4988_en.htm.

Griglio, Elena. "Post-Legislative Scrutiny as a Form of Executive, Oversight Tools and Practices in Europe". European Journal of Law Reform 2019 (21) 2, accessed July 7, 2019. doi: 10.5553/EJLR/138723702019021002004.

House of Lords, Select Committee on the Constitution. 14th Report of Session 200304: Parliament and the Legislative Process. London: The Stationery Office Limited, 2004). https://publications.parliament.uk/pa/ld200304/ldselect/ldconst/ 173/173.pdf.

Murphy, Jonathan, and Svitlana Mishura. "Post-legislative Scrutiny in a NonWestminster Parliament." European Journal of Law Reform 2 (2019). https:/www.elevenjournals.com/tijdschrift/ejlr/2019/2/EJLR_13872370_2019_021_002_003.

OECD, Better Regulation Practices across the European Union. Paris: OECD Publishing Paris, 2019. https://doi.org/10.1787/9789264311732-en.

OECD. Introductory Handbook for Undertaking Regulatory Impact Analysis (RIA), Version 1.0. 2008. http://www.oecd.org/gov/regulatory-policy/44789472.pdf.

OECD. Regulatory policy outlook 2018, October 10, 2018, https://doi.org/10.1787/ 9789264303072-en.

Opinion of the European Economic and Social Committee on Better Law Making. Official Journal C 24, 31 January 2006. Quoted in Clapinska, Lydia. "PostLegislative Scrutiny of Legislation Derived from the European Union.” MA thesis, Institute of Advanced Legal Studies, School of Advanced Study, 2006, 51. https://sas-space.sas.ac.uk/241/1/Lydia_Clapinska_MA_THESIS.pdf.

Opinion of Advocate General Bobek in Case C-528/16 - Confédération paysanne and Others, Court of Justice, January 2018, point 139. http://curia.europa.eu/juris/ celex.jsf.celex $=62016$ CC0528\&lang $1=$ en\&type $=$ TXT\&ancre $=$ 
Pîntea, Iurie and Vanhoutte, Peter. "Post-Legislative Scrutiny, practices, experiences and recommendations”, January 2017, Chisinau, Moldova, http://ipp.md/old /public/files/Publicatii/Post_legislative_scrutiny_practices_experiences__recomme ndations.pdf.

The Law Commission (LAW COM No 302). Post-legislative Scrutiny CM 6945. London: The Stationery Office Limited, 2006.

The Law Commission, Post-Legislative Scrutiny, Published as LAW COM No 302, London, October 2006, Post-legislative Scrutiny - The Government's Approach. Updating and improving the legislative process, Presented to Parliament By the Lord Privy Seal, Leader of the House of Commons and Minister for Women and Equality, March 2008, https:/www.gov.uk/government/uploads/system/uploads /attachment_data/file/228516/7320.pdf

Transparency Intenational, Georgia. "Institutionalization of Regulatory Impact Assessment (RIA) in Georgian Legislation.” Transparency International Georgia. Accessed June 3, 2019. https://www.transparency.ge/en/blog/institutionalizationregulatory-impact-assessment-ria-georgian-legislation.

The Parliament of Georgia. Explanatory Note of the Draft Amendments to the Law of Georgia on Normative Acts. Tbilisi: The Parliament of Georgia, 2019.

The Parliament of Georgia. Rules of Procedure of the Parliament of Georgia. Tbilisi: The Parliament of Georgia, 2019.

Website of the Parliament of the United Kingdom. Accessed May 30, 2019. https://www.parliament.uk/site-information/glossary/pre-legislative-scrutiny/.

Westminster Foundation for Democracy. Championing Parliamentary Oversight: The London Declaration on Post-legislative Scrutiny. London: Westminster Foundation for Democracy, 2018. https://www.wfd.org/wp-content/uploads/2019/ 03/2018-12-19-Declaration-on-PLS-EJLR.pdf.

Mr. Kuchava has been the Chairman of the Environmental Protection and Natural Resources Committee of the Parliament of Georgia since November 2016. Mr. Kuchava was elected as a Head of Parliamentary Delegation of GUAM and member of the OGP (Open Governance Partmenrship) council. Moreover, he is the president of the GUAM Parliamentary Assembly. During 2011 - 2015. Under Kuchava’s leadership as a CEO of "Georgian Copper and Gold" company was listed on London Stock Exchange. As a founder of the non-governmental organization "Georgian institute of Directors" (in May 2011). Mr. Kuchava holds Bachelor of Laws (Honours) from Tbilisi State University and the Master's degree in Corporate Law from Nottingham Law School. 